\title{
Efektivitas Penggunaan Game Analisis Training terhadap Peningkatan Kemampuan Berpikir Induktif Remaja
}

\author{
Wenda Novayani ${ }^{1}$, Heri Sasmita ${ }^{2}$ \\ ${ }^{1,2}$ Program Studi Teknik Komputer, Politeknik Caltex Riau \\ email:wenda@pcr.ac.id ${ }^{1}$,hrssmt0802@gmail.com ${ }^{2}$
}

(Received: 30 Oktober 2020/ Accepted: 30 November 2020 / Published Online: 20 Desember 2020)

\begin{abstract}
Abstrak
Penalaran induktif merupakan suatu langkah untuk mengambil kesimpulan yang bersifat umum dari hal-hal yang bersifat individual. Penalaran induktif dapat di ukur dengan Intelligent Structure (IST) sub ZR yaitu menggunakan pola angka dan dengan Inductive Reasoning Test (IRT) yaitu dengan pola gambar. Salah satu metode pembelajaran yang menarik dan menyenangkan dan pembelajarannya berpusat pada siswa yaitu media game edukasi. Penelitian ini bertujuan melihat efektivitas game dalam pembelajaran meningkatkan kemampuan berpikir induktif siswa SMP YKPP Sungai Pakning. Penelitian menggunakan metode pre-eksperimen dengan one group pretest-postest yang dilakukan pada 30 orang siswa kelas IX B sebagai subjek eksperimennya. Teknik pengumpulan data dilakukan dengan menggunakan instrument tes berupa soal essay sebanyak 20 soal untuk IST dan soal objektif sebanyak 30 soal untuk IRT. Materi yang digunakan dalam game ini juga telah melewati tahapan validasi yang dilakukan oleh seorang psikolog di kota Pekanbaru. Data dianalisis menggunakan TTest dan gain skor. Berdasarkan hasil penelitian, game ini diyakini $95 \%$ efektif meningkatkan kemampuan berpikir induktif remaja, dengan rata-rata peningkatan nilai 26.6 poin untuk form IST dan 17.8 poin untuk form IRT. Sehingga media pembelajaran dengan game efektif diterapkan pada pembelajaran induktif dan dapat dijadikan alternatif pembelajaran berpikir induktif disekolah SMP YKPP Sungai Pakning.
\end{abstract}

Kata kunci: Game Analysis Training, IST, IRT, Penalaran Induktif

\begin{abstract}
Inductive-reasoning is a step to draw general conclusions from individual matters. IR can be measured using the Intelligent Structure (IST) sub-ZR using a number pattern and using an Inductive Reasoning Test (IRT), which is an image pattern. One of the learning methods that are interesting and fun and student-cantered learning is Educational Game media. This study aims to see the effectiveness of games in learning to improve the students' inductive thinking skills at SMP YKPP Sungai Pakning. This study used a pre-experimental method with one group pretest-posttest conducted on 30 students of class IX B as the experimental subject. The data collection technique was implemented using a test instrument in 20 essay questions for IST and 30 objective questions for IRT. The material used in this game has also passed the validation stage carried out by a psychologist in Pekanbaru. Data were analyzed using the T-Test and score gain. Based on the study results, this game is believed to be $95 \%$ effective in improving adolescent inductive thinking skills, with an average increase of 26.6 points in the IST form and 17.8 points in the IRT form. Learning media with games are effectively applied to inductive-learning and can be used as an alternative to learning inductive-thinking at SMP YKPP Sungai Pakning.
\end{abstract}

Keywords: Analysis Training Game, IST, IRT, Inductive Thinking

\section{PENDAHULUAN}

Penalaran induktif adalah proses berpikir untuk menarik kesimpulan berupa prinsip atau sikap yang berlaku umum berdasarkan atas fakta-fakta yang bersifat khusus. Penalaran induktif identik dengan proses berpikir logis yang diawali dengan observasi data, 
pembahasan, dukungan pembuktian dan di akhiri dengan kesimpulan umum. Pengukuran pemikiran induktif dapat disajikan dalam bentuk numerik dan pola gambar. Penalaran induktif dengan urutan numerik disebut Intelligenz Structure Test (IST) subtes ZR, sedangkan penalaran induktif dengan pola bentuk atau gambar biasa di sebut dengan dengan Inductive Reasoning Test (IRT).

Menurut (Amthauer, 1953) IST merupakan salah satu jenis alat ukur yang mengukur konstruk inteligensi manusia. Sebagai alat ukur inteligensi, IST menghasilkan skor mean dalam konteks inteligensi yang disebut dengan Intelligence Quotient (IQ). IST sub-test Zahlen Reihen(ZR) yaitu pengujian penalaran berbentuk deretan numerik menggunakan pola tertentu, kemudian pola ini akan meminta untuk mengisi pola deretan angka selanjutnya. (Klauer \& Phye, 2008) mendefinisikan IRT sebagai suatu perbandingan sistematik dan analisis dari suatu objek yang ditujukan untuk menemukan keteraturan dalam suatu kekacauan nyata dan ketidak teraturan dalam urutan yang jelas. Keteraturan dan ketidak teraturan pada tingkat nominal diakui dengan membandingkan atribut elemen, misalnya, dari segi bentuk dan warna. Membandingkan suatu atribut ataupun hubungan dapat diarahkan melalui pencarian kemiripan, ketidakmiripan, atau keduanya.

Kemampuan berfikir induktif atau nalar sangat diperlukan oleh siswa, dimana dengan berpikir induktif siswa dapat mengelola, dan memanfaatkan infomasi untuk dapat dianalisa kebenaran atau tidaknya suatu informasi tersebut. Pengembangan siswa saat ini harus dititik beratkan pada kemampuan berpikir, yang melibatkan pemikiran krirtis, logis, sistematis, dan kreatif. Penalaran merupakan salah satu aspek dari kemampuan berpikir matematik tingkat tinggi yang harus dikuasai siswa sesuai dengan kurikulum disekolah. Masa pertumbuhan siswa pada usia SMP merupakan masa remaja, suatu peralihan dari masa anak-anak ke remaja. Pada masa yang singkat ini, siswa mengalami perkembangan secara signifikan dalam hidupnya, bukan hanya pada fisik, namun juga emosi, social, perilaku, intelektual, dan moral.

Berdasarkan wawancara dengan psikologis klinis di Pekanbaru (Yulial, 2019), bahwa apabila seseorang individu mengalami kesulitan dalam berpikir nalar atau berpikir induktif, maka hal tersebut dapat membuat seseorang menjadi orang yang tidak mandiri dan sulit mengatasi masalah-masalah yang dihadapi didalam kehidupan kesehariannya. Dimana kemampuan berpikir induktif merupakan suatu faktor penting dalam pembentukan karakter seseorang agar individu tersebut dapat menjadi pribadi yang dewasa dalam mengatasi masalah.

Pembelajaran berpikir induktif atau nalar disekolah diajarkan melalui pelajaran matematika. Di antara isu yang paling dominan dan sudah menjadi rahasia umum bahwa siswa menganggap pelajaran matematika sulit karena harus menggunakan semua pemikirannya untuk memahami penalaran. Metode pembelajaran resitasi pada mata pelajaran juga sudah dilakukan oleh (Ismatullah, 2017) dimana metode ini mengalami kelemahan diataranya kurangnya partisipasi siswa, sulit mengontrol dan mengawasi tugas yang dikerjakan oleh siswa. Hal ini sejalan dengan hasil interview yang telah dilakukan kepada guru Matematika SMP (Kasmawati, 2019) menyatakan bahwa siswa pada sekolah tersebut masih memiliki pemahaman yang rendah dalam proses penalaran pada pelajaran Matematika. Diantara penyebabnya yaitu kurangnya minat siswa pada pelajaran matematika, karena pelajaran ini dirasa sulit dipahami. Kemudian siswa juga kurang pemahami soal-soal yang diberikan guru, sehingga menyebabkan siswa selalu mengalami kebingungan ketika membaca soal dan tidak paham apa maksud dari pertanyaan yang diberikan. Apabila hal ini tidak segera diatasi, maka akan berpengaruh pada nilai akademik siswa-siswi didikannya. Hal ini sejalan dengan penelitian (Somatanaya, 2017) dimana semakin tinggi daya nalar seseorang berkontribusi sangat tinggi terhadap prestasi belajarnya.

Proses belajar yang menarik dan menyenangkan dapat disampaikan melalui game based learning (GBL). GBL sangat efektif untuk dijadikan sebagai media pembelajaran 
(Huizenga, Admiraal, Akkerman, \& Dam, 2009) dan sukses membuat generasi muda terlibat dalam proses pembelajaran yang lebih baik dari pada metode belajar secara tradisional (Gee, 2004; Prensky, 2001; Shaffer \& Gee, 2007). GBL efektif untuk mendorong ketertarikan dan mengajarkan pengetahuan (Randel, Morris, Wetzel, \& Whitehill, 1992), membuat pembelajaran jadi aktif yang menyenangkan (Huizenga, Admiraal, Akkerman, \& Ten Dam, 2009). Dalam pembuatan game, genre game harus di tentukan terlebih dahulu sebagaimana hasil penelitian (Novayani, 2019) bahwa ketepatan pemilihan genre game dengan konten dan metode pembelajaran sangat membantu dalam efektif atau tidaknya game dalam menyampaikan pembelajaran.

Penelitian pembelajaran matematika bagi siswa sekolah dasar dan remaja, diantaranya permainan tentang daya ingat melalui permainan oleh (Raymond, Suhatman, \& Dewi, 2018) dengan menggunakan speech recognition, namun jika digunakan ditempat keramaian siswa kesulitan. Pada penelitian (Hermawan, Herumurti, \& Kuswardayan, 2017) melihat efektifitas tiga genre game terhadap pembelajaran matematika matematika pada anak SD kelas 1-3, didapatkan game RPG fuzzel lebih efektif dibanding genre RPG dan Fuzzel dalam pembelajaran berhitung untuk anak SD, namun hasil efektifitasnya dalam kategori rendah jika dilihat dalam peningkatan pembelajarannya. Penelitian (Setiyawan, 2018) tentang game bingo untuk membantu proses berhitung bilangan pecahan, hasilnya siswa sekolah dasar terlihat aktif dalam pembelajaran, namun game ini hanya membahas perhitungan tidak kepada penalaran pemikirian siswa.

Sehingga, dengan komplek nya permasalahan dalam pembelajaran matematika terutama penalaran dan pentingnya pembelajaran berpikir induktif ini bagi remaja, dirasakan diperlukan suatu media alternatif yang menyenangkan dan menarik bagi remaja yaitu GBL yang kemudian game ini diberi nama game analisis training. Dimana didalam game ini diberikan dua metode pembelajaran penalaran menggunakan numerik (IST) dan dengan pola gambar (IRT). Oleh sebab itu, efektivitas game ini perlu diteliti terhadap kemampuan berpikir induktif remaja, dengan harapan dapat dijadikan media alternatif pembelajaran penalaran.

\section{METODE}

Penelitian ini menggunakan lembaran soal pada kertas pada saat pre-test dan soal dalam game untuk pengujian post-test untuk menguji efektivitas dari media pembelajaran melalui game. Pendekatan penelitian yang digunakan dalam penelitian ini true experiment dan kuantitatif untuk mengetahui peningkatan pemahama siswa. Jumlah sampel peserta yang digunakan adalah sebanyak 30 siswa dari populasi siswa kelas IX di SMP YKPP Sungai Pakning. Metode pengujian one group pre-test dan post-test digunakan untuk mendapatkan hasil efektivitas dari game dalam meningkatkan pemikirian induktif siswa.

Teknik Paired sample t-test dengan SPSS digunakan untuk melihat tingkat kepercayaan dan signifikan pengaruh game dalam peningkatan nilai pre-test dan post-test. Kemudian ngain skor untuk melihat interprestasi game, dimana ini digunakan untuk memperkuat analisa efektivitas penggunaan game peningkatan hasil belajar dengan menggunakan game analis training ini (lihat gambar 1). perhitungan n-gain ini dapat dilakukan dengan menggunakan rumus uji gain. Hasil perhitungan gain diinterpretasikan dengan menggunakan gain ternormalisasi dengan klasifikasi pada tabel 1.

$$
n-\text { gain }=\frac{\text { nilai post-test-nilai pre-test }}{\text { nilai maksimum-nilai pre-test }}
$$


Tabel 1. Indek Nilai Gain

\begin{tabular}{cc}
\hline Nilai Gain & Interprestasi \\
\hline $\mathbf{0 . 7}<$ gain $<\mathbf{1}$ & Tinggi \\
$\mathbf{0 . 3} \leq$ gain $\leq \mathbf{0 . 7}$ & Sedang \\
$\mathbf{0}<$ gain $<\mathbf{0 . 3}$ & Rendah \\
\hline
\end{tabular}

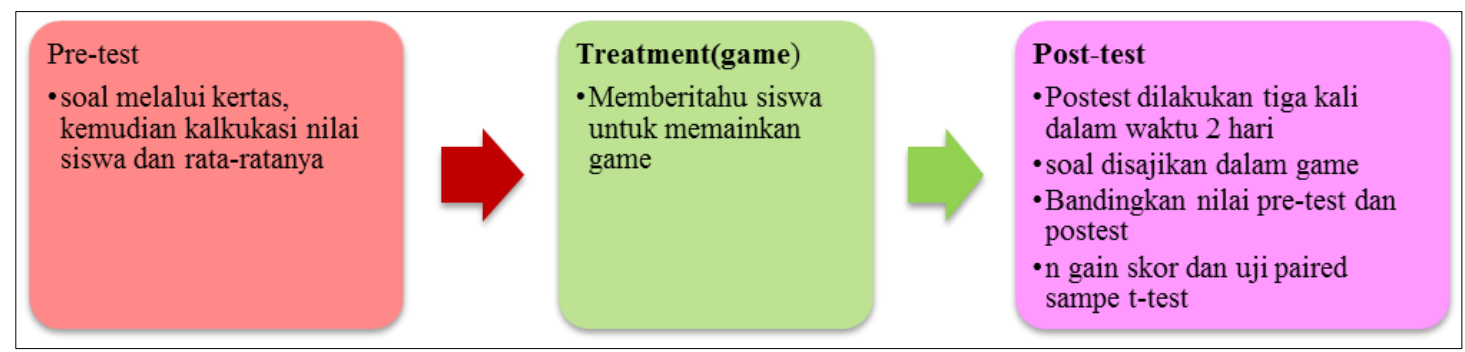

Gambar 1. Alur Proses Analisa Hasil Penelitian

\section{HASIL DAN PEMBAHASAN}

Hasil

\section{Game Analisis Training}

Game yang telah dibuat diberi nama game analisis training. Hasil perancangan antar muka game ini dapat dilihat pada Gambar 1. Pada saat pemain telah mengisi data diri dan menekan tombol mulai, maka akan tampil halaman menu game yang terdiri dari beberapa tombol, diantaranya tombol "Mulai Permainan", "Lihat Score", "Tentang Aplikasi", dan "Keluar". Kemudian ketika pemain menekan tombol "mulai permainan", maka pada layar seluler pemain akan dibawa pindah ke halaman menu pilihan berupa form yang tersedia, yakni Intelligenz Structure Test dan Inductive Reasoning Test. Ketika pemain menekan tombol "Lihat Score", maka akan pindah ke halaman skor yang terdiri dari skor Intelligenz Structure Test dan Inductive Reasoning Test. Pada saat pemain memilih salah satu form yang tersedia, maka akan ditampilkan halaman metode menjawab pada layar seluler pemain, kemudian pemain bisa memilih ingin menjawab menggunakan speech recognition ataupun menggunakan tombol pilihan.

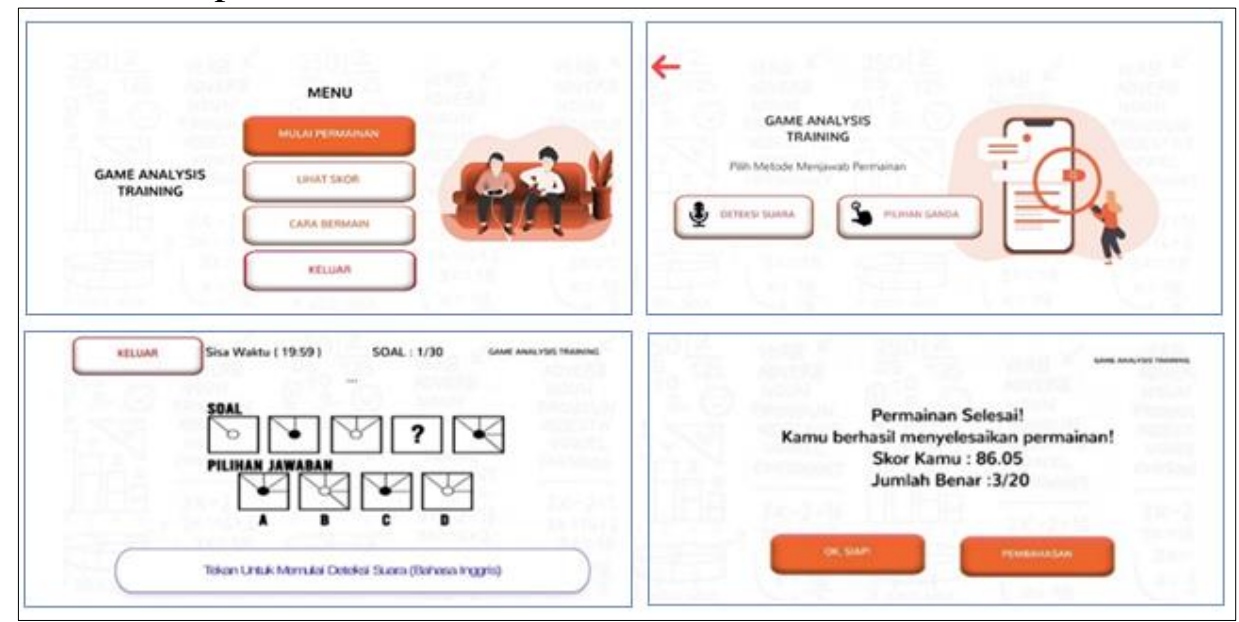

Gambar 2. Tampilan Fitur Game Analysis Training

Jika pemain selesai melakukan pengisian pada semua soal yang terdapat pada tes yang diambil maka game akan menampilkan hasil berupa score dan informasi jumlah soal yang dijawab benar oleh pemain. Kemudian juga terdapat fitur pembahasan yang memungkinkan pemain dapat melakukan pemeriksaan jawaban yang dilakukan sebelumnya, data jawaban 
yang telah dilakukan oleh pemain saat mengisi form secara otomatis ditampung pada data cache dan apabila jawaban yang diberi oleh pemain adalah "benar", maka akan dijumlahkan berdasarkan score yang telah ditentukan pada aplikasi.

\section{Hasil Analisa Pengujian Efektifivitas Game}

Pengujian dilakukan menggunakan one group pre-test dan post-test kepada 30 orang siswa IX SMP sebanyak 3 kali dengan treatment belajar dalam waktu 2 hari kemudian kembali membuka game analysis training untuk melihat apakah terdapat peningkatan dalam kemampuan analisa soal. Pengujian hasil pembelajaran berpikir induktif dilakukan dengan menggunakan form IST untuk analisis numerik dan IRT untuk analsis pola gambar.

Deskripsi hasil pengujian IST dengan eksperimen yang telah dilakukan di tampilkan dalam tabel 2 dan grafik frekuensi persebaran nilai IST nya dapat dilihat pada gambar 3 . Berdasarkan data pada tabel 2 dan data persebaran nilai pada gambar 3, nilai pre-test dan post-test dengan penalaran numerik atau IST pada saat pre-tes mempunya nilai minimum 25 dan maksimal 95 dengan rata-rata nilai 58.5, nilai paling banyak berada pada angka range nilai 25-50 yaitu 14 orang. Kemudian pada hasil siswa memainkan game, post-test1 mengalami perubahan dengan nilai minimum 40 dan maksimum 100 dengan rata-rata 78.5, nilai paling banyak berada pada range $76-100$ yaitu 17 orang.

Tabel 2. Deskripsi Statistik Nilai Pre-tes dan Post-tes Pengujian IST

\begin{tabular}{|c|c|c|c|c|c|c|c|}
\hline \multirow[t]{2}{*}{ Jenis Test } & \multicolumn{3}{|c|}{ Frekuensi Range Nilai } & \multicolumn{3}{|c|}{ Nilai } & \multirow[t]{2}{*}{ n-gain } \\
\hline & $25-50$ & $51-75$ & $76-100$ & Minimum & Maksimum & Rata-rata & \\
\hline Pretest & 14 & 13 & 3 & 25 & 95 & 58,5 & \\
\hline Post-test 1 & 2 & 11 & 17 & 40 & 100 & 78,5 & 0,5 \\
\hline Post-test 2 & 0 & 9 & 21 & 65 & 100 & 85,5 & 0,7 \\
\hline Post-test 3 & 0 & 3 & 27 & 75 & 100 & 91,5 & 0,8 \\
\hline
\end{tabular}

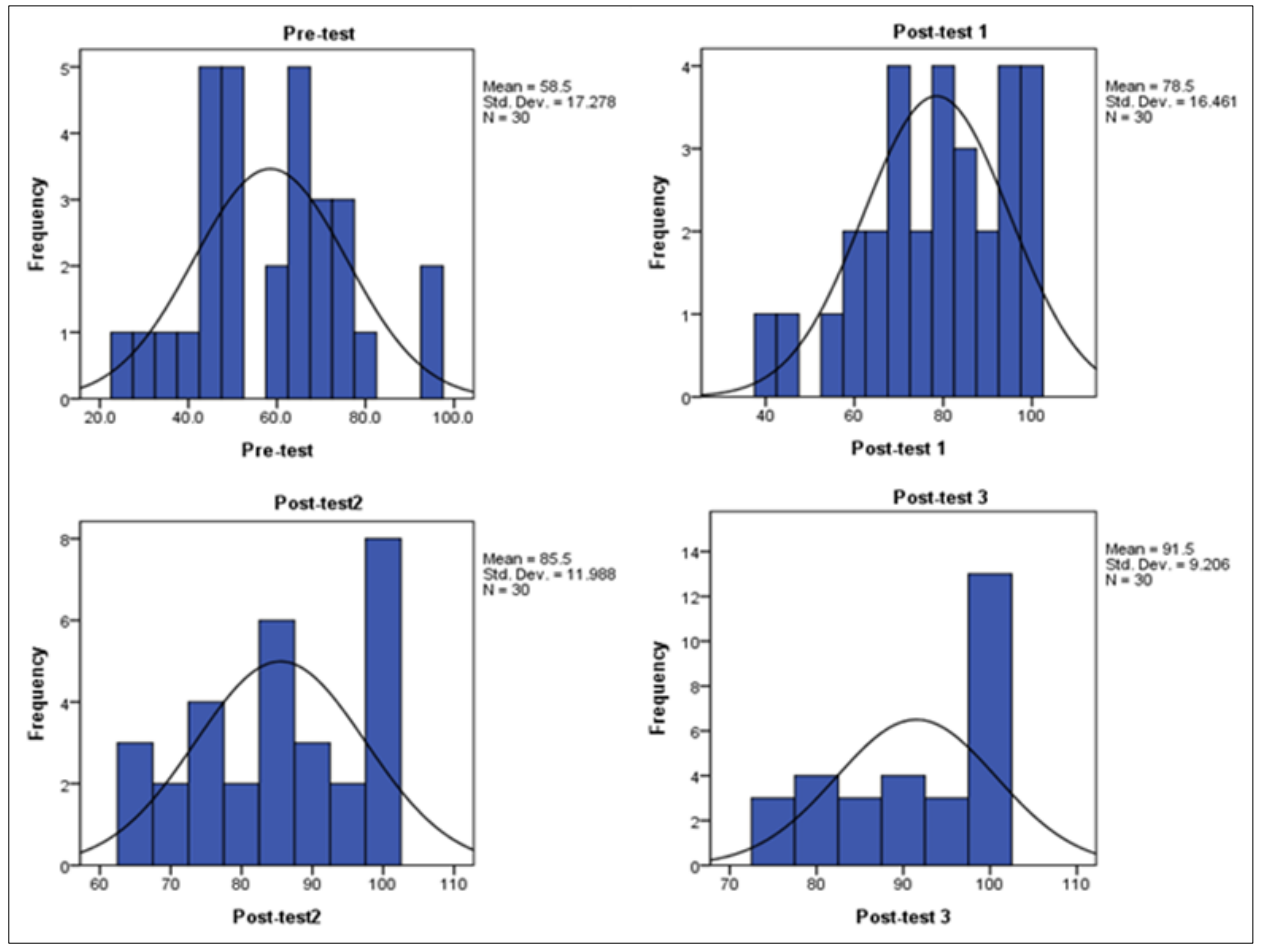

Gambar 3. Frekuensi Persebaran Nilai Pre-test dan Post-test IST 
Post-test ke dua mengalami peningkatan dengan nilai minimum 65 dan maksimum 100 dengan rata-rata nilai 85.5, nilai paling banyak berada range 76-100 yaitu 21 orang. Kemudian dilakukan post-test terakhir yaitu pos-test ke tiga, siswa mendapatkan peningkatan nilai dengan nilai minimum 75 dan maksimal 100 dimana rata-rata 91.5, nilai paling banyak berada pada range $76-100$ yaitu 27 orang.

Nilai n-gain pada post-test pertama dan kedua termasuk dalam kategori interprestasi sedang dimana dengan nilai secara berurutan sebesar 0.5 dan 0.7 , sedangkan pada post-test ketiga termasuk dalam kategori interprestasi tinggi dengan nilai 0.8. Dengan kata lain game ini mempunyai pengaruh yang signifikan terhadap hasil belajar dengan game dilihat dari nilai pre-tets dan post-test. Sehingga berdasarkan data pengujian maka pada Intelligenz Structure Test, jika dirata-ratakan test 1, 2 dan 3 maka nilai rata-ratanya 85.1 atau naik 26.6 point dibandingkan dengan pre-test. grafik peningkatan nilai pre-tes dan postest dengan tiga kali percobaan seperti berikut pada gambar 4 .

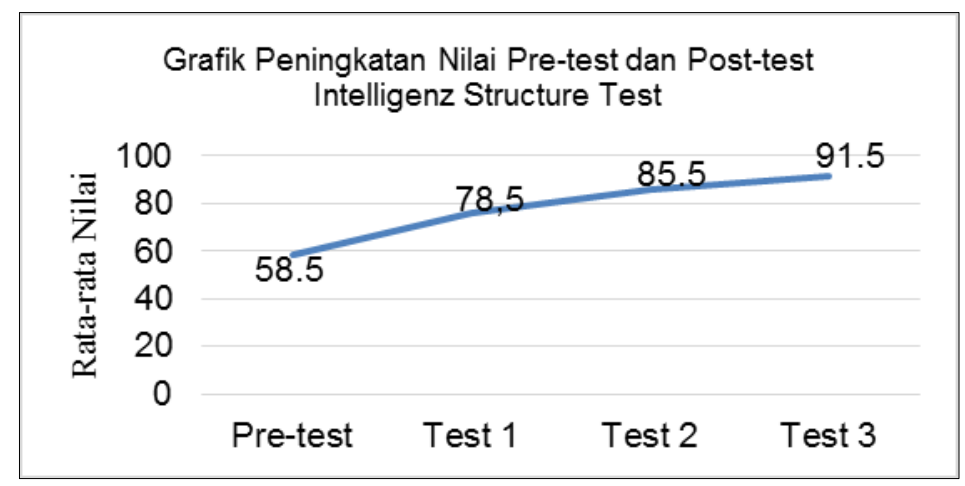

Gambar 4. Grafik Peningkatan Hasil Pengujian IST

Pengujian Paired T-test dilakukan pada data pre-test dan post-test1 (pertama), penggunaan post test 1 dilakukan untuk agar terlihat pada saat post test 1 saja apakah sudah memberikan hasil yang signifikan atau belum, jika post test pertama saja sudah signifikan perbedaannya, maka post-test kedua dan ketiga pasti demikian jika dilihat dari nilai pada tabel 3 adalah hasil pengujian paired t-test dari IST dengan tingkat kepercayaan $95 \%$.

Tabel 3. Tabel Paired Samples Test Pengujian IST

\begin{tabular}{lccrrr}
\hline & $95 \%$ Confidence Interval of the & df & Sig. (2-tailed) \\
& \multicolumn{2}{c}{ Difference } & & \\
\cline { 1 - 3 } Pre-test - Post-test 1 & Lower & Upper & & \\
\hline
\end{tabular}

Berdasarkan data pada tabel 3, dinyatakan bahwa nilai signifikan 2-tailed bernilai 0,000 yang mana menurut aturan SPSS, apabila nilai signifikan 2-tailed $<0,05$, maka terdapat perbedaan signifikan dari pre-test dan post-test dengan tingkat kepercayaan 95\%. Dengan demikian, bahwa game analisis training ini mampu memberikan peningkatan belajar berpikir induktif dengan penalaran numerik (IST) secara signifikan (kepercayaan 95\%) kepada siswa.

Deskripsi hasil pengujian IRT dengan eksperimen yang telah dilakukan di tampilkan dalam tabel 4 dan grafik frekuensi persebaran nilai IRT nya dapat dilihat pada gambar 5 . Berdasarkan data pada Tabel 4 dan persebaran nilai pada Gambar 5, dimana nilai pre-test dan post-test dengan penalaran pola gambar atau IRT pada saat pre-tes mempunya nilai minimum 30 dan maksimal 81 dengan rata-rata nilai 54.3, nilai paling banyak berada pada 51-75 yaitu 15 orang. 
Tabel 4. Frekuensi Nilai Pre-tes dan Post-tes Pengujian IRT

\begin{tabular}{lccccccc}
\hline Jenis Test & \multicolumn{6}{c}{ Frekuensi Range Nilai } & \multicolumn{3}{c}{ Nilai } & n-gain \\
\cline { 2 - 8 } & $25-50$ & $51-75$ & $76-100$ & Minimum & Maximum & Rata-rata & \\
Pretest & 13 & 15 & 2 & 30 & 81 & 54.30 & \\
Post-test 1 & 3 & 19 & 8 & 30 & 87 & 64.80 & 0,2 \\
Post-test 2 & 1 & 18 & 11 & 45 & 87 & 71.70 & 0,4 \\
Post-test 3 & 0 & 9 & 21 & 60 & 90 & 79.80 & 0,6 \\
\hline
\end{tabular}

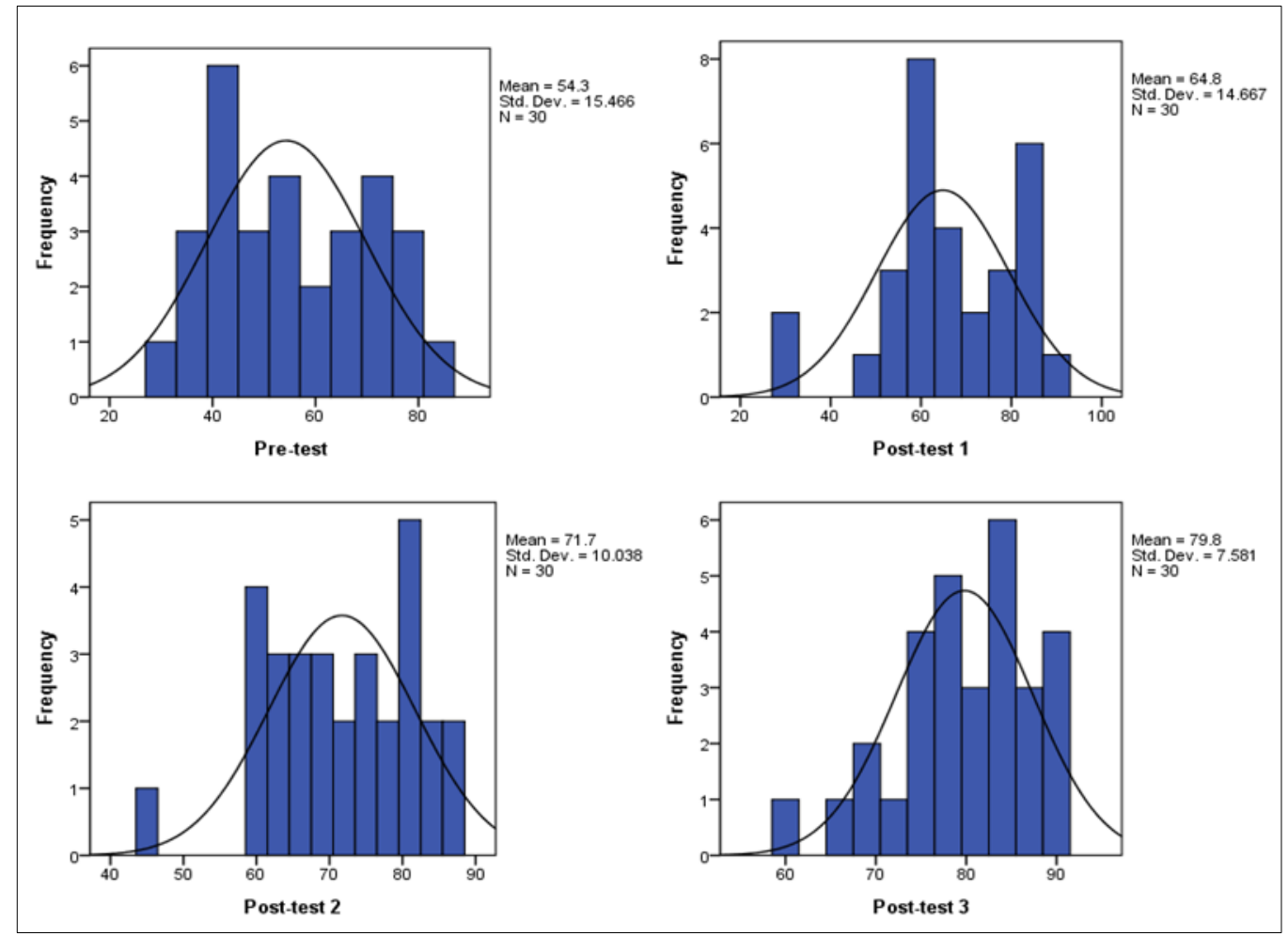

Gambar 5. Grafik Frekuensi Persebaran Nilai Pre-test dan Post-test IRT

Pada post-test pertama nilai minimum tetap 30 dan namun nilai maksimum meningkat menjadi 87 dengan rata-rata 64.8, nilai paling banyak berada pada range 51-75 yaitu 19 orang. Post-test ke dua mengalami peningkatan dengan nilai minimum 45 dan maksimum tetap berada di angka 87 dengan rata-rata nilai 71.7, nilai paling banyak berada pada range 51-75 yaitu 18 orang. Nilai post-test ketiga nilai minimum 60 dan maksimal 90 dimana ratarata 79.8, nilai paling banyak berada pada range 76-100 yaitu 21 orang.

Nilai n-gain pada post-test pertama dengan nilai 0,2 termasuk dalam kategori rendah, namun pada post-test ke dua dan ketiga terdapat peningkatan yaitu menjadi 0,4 dan 0,6 dimana game ini memberikan pengaruh yang sedang terhadap pengingkatan pengetahuan pembelajaran induktif untuk pola gambar. Sehingga berdasarkan data pengujian maka pada Inductive Reasoning Test, jika dirata-ratakan test 1, 2 dan 3 maka nilai rata-ratanya 72.1 atau naik 17.8 point dibandingkan dengan pre-test. grafik peningkatan nilai pre-tes dan postest seperti pada gambar 6. Berdasarkan data pada gambar 6, terlihat bahwa rata-rata nilai dari siswa yang melakukan post-test mengalami peningkatan nilai rata-rata. Pengujian Paired TTest dilakukan pada data Pre-Test dan Post Test yang pertama dari IRT dengan tingkat kepercayaan $95 \%$. Berdasarkan data pada tabel 5, dinyatakan bahwa nilai signifikan 2-tailed bernilai 0,000 yang mana menurut aturan spss, apabila nilai signifikan 2 -tailed $<0,05$, maka terdapat perbedaan signifikan dari pretest dan hasil posttest pertama dengan tingkat kepercayaan $95 \%$. 


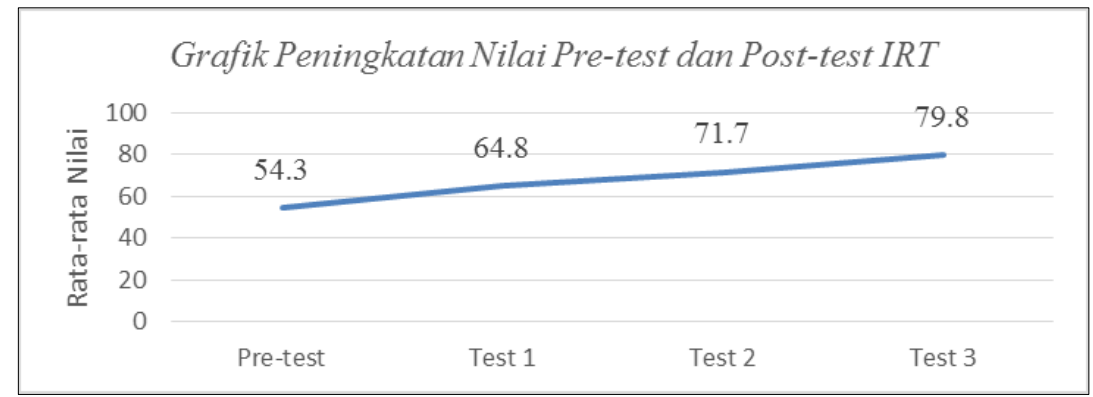

Gambar 6. Grafik Peningkatan Hasil Pengujian IRT

Tabel 5. Tabel Pengujian Paired Samples T-test nilai pretest dan Post-test IRT

\begin{tabular}{lcccr}
\hline & $95 \%$ Confidence Interval of the & df & Sig. (2-tailed) \\
& \multicolumn{2}{c}{ Difference } & & \\
\cline { 1 - 3 } Pre-test - Post-test 1 & Lower & Upper & & \\
\hline
\end{tabular}

\section{Pembahasan}

Melalui hasil pengujian yang dilakukan, didapatkan kenaikan rata-rata persentasi kebenaran dari tes yang dilakukan oleh siswa, ini menandakan perkembangan yang baik untuk siswa sehingga dapat secara tidak langsung mengasah kemampuan berpikir induktif dengan cara yang menyenangkan bagi siswa yaitu melalui game. Pada form IST terdapat perubahan dalam kategori tinggi antara pre-test ke post-test pertama, dua dan tiga. Sehingga dapat dikatakan game ini memberikan pengaruh yang tinggi terhadap peningkatan kemampuan berpikir induktif untuk pembelajaran penalaran numerik. Namun pada form IRT, game ini memberikan pengaruh sedang terhadap peningkatan kemampuan berpikir induktif dalam menganalisa secara induktif untuk kategori pola gambar. Sehingga media game analisis training yang berbasis game based learning ini efektif sebagai media alternative pembelajaran yang menarik dan menyenangkan dalam menyampaikan materi pemikirian induktif bagi remaja. Dari hasil pengujian, siswa lebih mudah memahami penalaran menggunakan numerik dibandingkan penalaran menggunakan pola gambar.

Hasil penelitian ini relevan dengan beberapa penelitian yang menyatakan bahwa penerapan metode pembelajaran melaui game edukasi menyenangkan dan efektif digunakan untuk meningkatkan hasil belajar siswa (Huizenga, Admiraal, Akkerman, \& Dam, 2009; Shaffer \& Gee, 2007; Hermawan et al., 2017; Raymond et al., 2018; Setiyawan, 2018). Pembelajaran dengan menerapan metode pembelajaran menggunakan game edukasi dalam penelitian ini sudah meningkat nilai siswa dengan kepercayaan 95\%. Dengan demikian, maka efektivitas penggunaan game dalam pembelajaran sudah tercapai. Berdasarkan hasil signifikan dengan tingkat kepercayaan $95 \%$ dan nilai $\mathrm{n}$ gain skor maka penerapan metode pembelajaran penelaran induktif melalui game telah memenuhi syarat sebagai pembelajaran yang efektif.

\section{SIMPULAN}

Berdasarkan hasil pengujian dan analisa yang telah dilakukan, game ini diyakini $95 \%$ mampu meningkatkan kemampuan berpikir induktif remaja. Rata-rata peningkatan nilai siswa untuk pola penalaran induktif berupa numerik (IST) sebesar 26.6, dan meningkat 17.8 poin untuk penalaran induktif berupa dengan pola gambar (IRT). Dengan demikian, media game edukasi efektif dijadikan sebagai media pembelajaran alternative yang menarik dan menyenangkan dalam pembelajaran pemikiran induksi untuk remaja. Sehingga penggunaan media pembelajaran melalui game edukasi perlu dilakukan disekolah agar siswa senang dalam belajar dan dapat termotivasi. 


\section{REFERENSI}

Amthauer, R. (1953). Intelligenz-Struktur-Test: I-S-T (2nd ed.). Hogrefe.

Gee, J. P. (2004). What Video Games Have to Teach Us about Learning and Literacy. Education + Training, 46(4), 175-178. https://doi.org/10.1108/et.2004.00446dae.002

Hermawan, D. P., Herumurti, D., \& Kuswardayan, I. (2017). Efektivitas Penggunaan Game Edukasi Berjenis Puzzle, RPG dan Puzzle RPG Sebagai Sarana Belajar Matematika. JUTI: Jurnal Ilmiah Teknologi Informasi, 15(2), 195-205. https://doi.org/10.12962/j24068535.v15i2.a663

Huizenga, J., Admiraal, W., Akkerman, S., \& Ten Dam, G. (2009). Mobile game-based learning in secondary education: engagement, motivation and learning in a mobile city game: Original article. Journal of Computer Assisted Learning, 25(4), 332-344. https://doi.org/10.1111/j.1365-2729.2009.00316.x

Ismatullah, K. (2017). Penerapan Metode Pembelajaran Resitasi dalam Pembelajaran Matematika Dasar. Edumatic: Jurnal Pendidikan Informatika, 1(1), 24-28. https://doi.org/10.29408/edumatic.v1i1.734

Kasmawati, S. (2019). Metode Pembelajaran. Hasil Wawancara Guru Matematika: 20 Maret 2019, SMP YKPP Sungai Pakning.

Klauer, K. J., \& Phye, G. D. (2008). Inductive reasoning: A training approach. Review of Educational Research, 78(1), 85-123. https://doi.org/10.3102/0034654307313402

Novayani, W. (2019). Game Genre untuk Permainan Pembelajaran Sejarah Berdasarkan Kebutuhan Pedagogi dan Learning Content. Jurnal Komputer Terapan, 5(2), 54-63.

Prensky, M. (2001). Digital Natives, Digital Immigrants. On the Horizon, 9(5), 1-6. https://doi.org/10.1108/10748120110424816

Randel, J. M., Morris, B. A., Wetzel, C. D., \& Whitehill, B. V. (1992). The effectiveness of games for educational purposes: A review of recent research. Simulation \& Gaming. Simulation \& Gaming, 23(3), 261-276.

Raymond, R., Suhatman, R., \& Dewi, M. (2018). Pembangunan Game Memory Training terhadap Peningkatan Short Term Memory (STM) pada Anak SMP Menggunakan Speech Recognition (Studi Kasus: SMP Dharma Loka Pekanbaru). Jurnal Nasional Teknologi Dan Sistem Informasi, 4(2), 61-72. https://doi.org/10.25077/teknosi.v4i2.2018.61-72

Setiyawan, H. (2018). Metode Permainan Bingo Matematik pada Materi Operasi Hitung Pecahan Terhadap Hasil Belajar Siswa Kelas IV. Matematika dan Pembelajaran, 6(2), 101-110.. https://doi.org/10.33477/mp.v6i2.662

Shaffer, D. W., \& Gee, J. P. (2007). How Computer Games Help Children Learn. USA: Palgrave Macmillan. https://doi.org/10.1057/9780230601994

Somatanaya, A. G. (2017). Analisis Kemampuan Berfikir Nalar Matematis Serta Kontribusinya Terhadap Prestasi Belajar Mahasiswa (Studi Terhadap Mahasiswa FKIP Pendidikan Matematika Universitas Siliwangi). Teorema: Teori dan Riset Matematika, 1(2), 55-62. https://doi.org/10.25157/teorema.v1i2.547

Yulial, E. (2019). Penalaran Induktif. Wawancara Langsung dengan Erni Yulial Psikolog Klinis: 20 Juni, Pekanbaru. 